\title{
Selective isolation of cationic amino acids and peptides by electro-membrane filtration
}

\author{
Gerrald BARGEMAN $^{\mathrm{a} *}$, Monique DOHMEN-SPEELMANS ${ }^{\mathrm{a}}$, \\ Isidra RECIO ${ }^{\mathrm{b}}$, Martin TIMMER ${ }^{\mathrm{c}}$, Caroline VAN DER HORST ${ }^{\mathrm{a}}$ \\ a Department Process Innovation, NIZO food research, P.O. Box 20, Ede 6710 BA, The Netherlands \\ ${ }^{\mathrm{b}}$ Department Product Technology, NIZO food research, \\ P.O. Box 20, Ede 6710 BA, The Netherlands \\ c Timmer Technology Development and Consultancy, Bospoort 11A, \\ Ede 6711 BT, The Netherlands
}

\begin{abstract}
In the food industry there is a clear trend towards the production of speciality products with a high added value. Electro-membrane filtration (EMF) can be used to separate and concentrate these products from complex solutions. With EMF, lysine was separated from a model solution and a protein hydrolysate both containing leucine. The lysine fraction in the permeate ranged from 0.86 to 0.96 . The lysine transport rate and purity were improved by increasing the potential difference from $20 \mathrm{~V}$ to $40 \mathrm{~V}$. Reduction of the transmembrane pressure from 2 to 0.5 bar improved the purity at a practically unchanged lysine transport rate. An enriched fraction of antibacterial cationic peptides (e.g. lactoferricin-B) could be produced from a lactoferrin hydrolysate using EMF. Isolation of these bioactive peptides is normally expensive due to the complex nature of the hydrolysate feed. EMF has the potential to become an attractive (partial) isolation technology.
\end{abstract}

electro-membrane filtration / dairy / food / lactoferricin / separation

\section{INTRODUCTION}

The current trend in the food industry is to produce speciality products with a high added value, especially nutraceuticals. Consequently, there is an increasing need for isolating and purifying high-value components (e.g. amino acids, bioactive peptides) from complex solutions such as protein hydrolysates. For the production of these components chromatographic techniques are usually required. Since this is capital intensive, alternative easily up-scalable technologies are under investigation.

Membrane filtration (ultrafiltration or nanofiltration) can be used to separate

\footnotetext{
* Correspondence and reprints. bargeman @ nizo.nl
} 
ampholytes (amino acids, peptides and proteins) selectively from complex solutions by manipulating the charge interactions between the components and the membrane surface $[4,5,7,9,16-19,21]$. This can be achieved by adjusting the $\mathrm{pH}$ or by adapting the salt composition of the feed. Even amino acids of similar size (e.g. leucine and lysine) can be separated with high selectivity $[17,18]$. The highest selectivity is obtained when size exclusion is (almost) absent and the Donnan exclusion mechanism dominates [18].

The separation efficiency can also be manipulated and improved by the introduction of an external potential difference over the (nanofiltration, ultrafiltration or microfiltration) membrane $[2,6,15,20]$. This was originally proposed to reduce concentration polarisation of proteins at the membrane surface, thereby increasing the permeate flux [10, 13, 14, 22]. Recently this has received more and more attention for the production of speciality products due to the effect of the electric field on retention of charged components. Van Nunen [20] estimated, on the basis of pilot-scale $\left(0.25 \mathrm{~m}^{2}\right.$ membrane area) experiments, that the costs for separating the proteins lipase and lysozyme with a multi-compartment electro-membrane filtration (EMF) system would be around 50 Euro per kg protein produced.

Because of the industrial need for alternative cost-effective separation methods for the production of high-value products and our knowledge on the effects of charge interactions between membranes and these components on the separation efficiency, we have performed initial experiments with EMF to study the possibilities of this process. The separation of the amino acids leucine (Leu) and lysine (Lys) from a model solution and a commercial protein hydrolysate and the isolation of antibacterial cationic peptides (in particular lactoferricin-B, Lfcin-B) from a peptic hydrolysate of lactoferrin (LF) are presented in this article.

\section{MATERIALS AND METHODS}

\subsection{Membrane module}

The membrane filtration module (Fig. 1) contains a high-voltage power supply to provide the required electric field strength. The field strength over the membrane can be measured (Fig. 1). During the experiments the anode was situated in the electrode compartment next to the feed/concentrate compartment and the cathode was placed in the electrode compartment next to the permeate compartment. A polymeric NTR 7450 (Nitto-Denko, Shiga, Japan, MWCO $1 \mathrm{~kg} \cdot \mathrm{mol}^{-1}$ ) flat-sheet membrane was used for the separation of leucine and lysine from a model solution and a protein hydrolysate. Isolation of cationic peptides from a LF hydrolysate was done with a more open polysulphone flat-sheet membrane (MWCO $10 \mathrm{~kg} \cdot \mathrm{mol}^{-1}$ ) to minimise size exclusion. The installed membrane area was $0.008 \mathrm{~m}^{2}$. The electrode compartments were separated from the feed/concentrate and the permeate compartment with a CMX and an AMX ion-exchange membrane, respectively, from Tokuyama Soda, Tokyo, Japan. $\mathrm{pH}$ indicators were placed in all collection/supply beakers (Fig. 1) to monitor the $\mathrm{pH}$ variations as a result of water splitting reactions at the ion-exchange membranes.

\subsection{Feedstock solutions}

A model solution containing approximately $5 \mathrm{mmol} \cdot \mathrm{L}^{-1}$ leucine (molecular weight $131 \mathrm{~g} \cdot \mathrm{mol}^{-1}$ ) and lysine (molecular weight $146 \mathrm{~g} \cdot \mathrm{mol}^{-1}$ ) was prepared by dissolving analytical-grade leucine and lysine (Sigma, St-Louis, MO, USA) in reverse osmosis permeate of de-mineralised water (RO de-min. water). The $\mathrm{pH}$ was adjusted to 5.5 with $\mathrm{HCl}$.

A $1 \% \mathrm{w} / \mathrm{w}$ casein hydrolysate solution containing approximately $3 \mathrm{mmol} \cdot \mathrm{L}^{-1}$ lysine and leucine was prepared by dissolving casein hydrolysate (Pepticase, Sheffield 


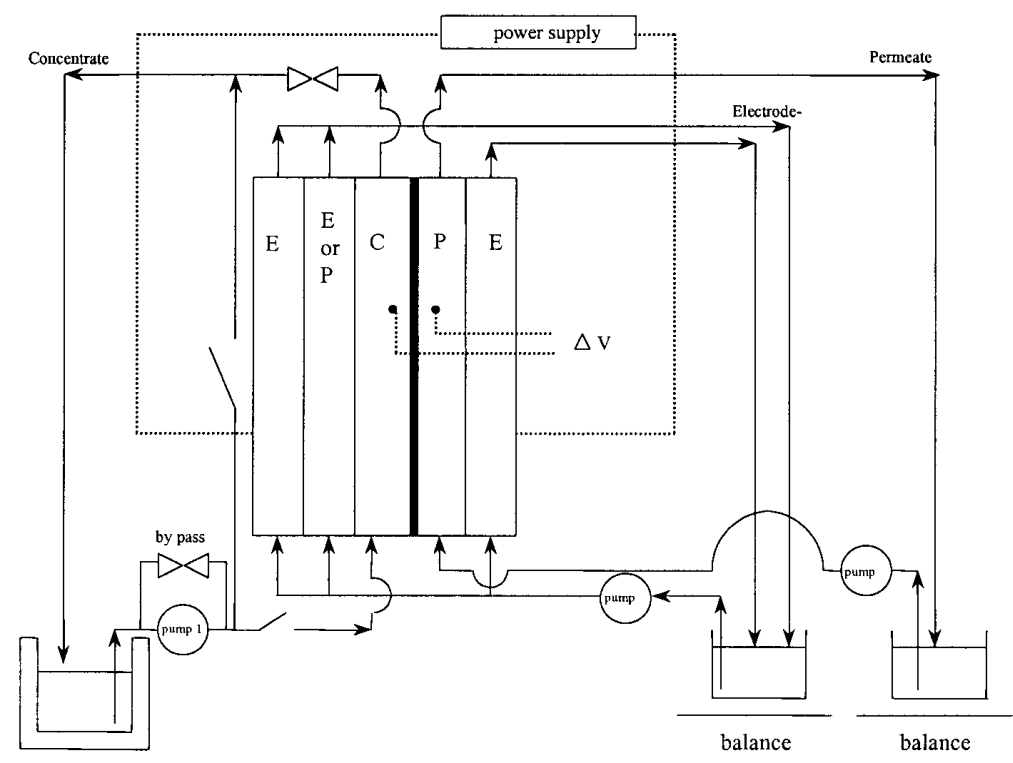

Figure 1. Schematic representation of the EMF test-rig (E electrode compartment, P permeate compartment, $\mathrm{C}$ concentrate/feed compartment).

Products, Norwich, USA) in RO de-min. water. The $\mathrm{pH}$ of the solution was 7.3.

Bovine LF was kindly supplied by Domo Food Ingredients (Beilen, The Netherlands). A $5 \% \mathrm{w} / \mathrm{v}$ aqueous solution of LF was adjusted to $\mathrm{pH} 3.0$ with $1.0 \mathrm{~mol} \cdot \mathrm{L}^{-1} \mathrm{HCl}$ and digested with $3 \% \mathrm{w}$ porcine pepsin A (EC 3.4.23.1, $445 \mathrm{U} \cdot \mathrm{mg}^{-1}$ solid, from Sigma)/w of substrate for $4 \mathrm{~h}$ at $37^{\circ} \mathrm{C}$. Heating at $80^{\circ} \mathrm{C}$ for $15 \mathrm{~min}$ and adjusting the $\mathrm{pH}$ to 7.0 with $1 \mathrm{~mol} \cdot \mathrm{L}^{-1} \mathrm{NaOH}$ terminated the reaction. The digest was centrifuged at $16000 \mathrm{~g}$ for $15 \mathrm{~min}$ and the supernatant was retained and freeze-dried. The dried hydrolysate was re-dissolved in twice-distilled water $(0.8 \%$ $\mathrm{w} / \mathrm{v}$ final concentration) and the $\mathrm{pH}$ was adjusted to 8.5 . Subsequently the hydrolysate was centrifuged again. The supernatant was used as feed solution for the EMF system.

\subsection{Experiments and methods}

All experiments (Tab. I) were carried out at $25{ }^{\circ} \mathrm{C}$ with a $0.01 \mathrm{~mol} \cdot \mathrm{L}^{-1} \mathrm{Na}_{2} \mathrm{SO}_{4}$ (ana- lytical grade, obtained from Merck, Darmstadt, Germany) solution in the electrode compartments. $\mathrm{A} \mathrm{Na}_{2} \mathrm{SO}_{4}$ solution is preferred over $\mathrm{NaCl}$ to avoid the production of $\mathrm{Cl}_{2}$ at the anode. The concentrate, permeate and electrode solution were circulated over beakers at a circulation rate of $175 \mathrm{~L} \cdot \mathrm{h}^{-1}, 50 \mathrm{~L} \cdot \mathrm{h}^{-1}$ and $50 \mathrm{~L} \cdot \mathrm{h}^{-1}$, respectively. The unit was thus operated batch wise not only for the feed/concentrate and electrode solution, but also for the permeate. Due to this operation mode the lysine selectivity can not be determined. The lysine fraction in the permeate, however, gives an indication of the selectivity. This fraction is defined as:

$$
f=\frac{\mathrm{c}(\text { Lys })_{p}}{\mathrm{c}(\text { Lys })_{p}+\mathrm{c}(\text { Leu })_{p}}
$$

where $c(\text { Lys })_{p}$ represents the lysine concentration and $\mathrm{c}(\mathrm{Leu})_{p}$ the leucine concentration in the permeate. The $\mathrm{pH}$ of the feed (concentrate) and in some cases of the permeate (Tab. I) was adjusted continuously and kept between 4 and 8 for the 
Table I. Summary of the experiments (RO demin. water: reverse osmosis permeate of de-mineralised water, V: potential difference set-point of the power supply, C: concentrate, P: permeate).

\begin{tabular}{lccccc}
\hline $\begin{array}{l}\text { Exp. } \\
\text { No. }\end{array}$ & Feed & $\begin{array}{c}\text { Permeate solution } \\
\text { at start of run }\end{array}$ & $\begin{array}{c}\mathrm{V} \\
(\mathrm{V})\end{array}$ & $\begin{array}{c}\text { TMP } \\
\text { (bar) }\end{array}$ & $\begin{array}{c}\text { PH } \\
\text { adjustment }\end{array}$ \\
\hline 1 & Leu/Lys model solution & $0.01 \mathrm{~mol} \cdot \mathrm{L}^{-1} \mathrm{Na}_{2} \mathrm{SO}_{4}$ & 40 & 2 & $\mathrm{C}$ and P \\
2 & Leu/Lys model solution & $0.01 \mathrm{~mol} \cdot \mathrm{L}^{-1} \mathrm{Na}_{2} \mathrm{SO}_{4}$ & 40 & 0.5 & $\mathrm{C}$ and P \\
3 & Leu/Lys model solution & RO de-min $\cdot \mathrm{water}$ & 40 & 0.5 & $\mathrm{C}$ \\
4 & Leu/Lys model solution & $0.01 \mathrm{~mol} \cdot \mathrm{L}^{-1} \mathrm{Na}_{2} \mathrm{SO}_{4}$ & 20 & 2 & $\mathrm{C}$ \\
5 & $1 \%$ w/w casein hydrolysate & RO de-min. water & 40 & 0.05 & $\mathrm{C}$ and P \\
6 & $0.8 \%$ w/w LF hydrolysate & RO de-min. water & 40 & 0.05 & $\mathrm{C}$ and P \\
\hline
\end{tabular}

leucinelysine separation experiments. In this $\mathrm{pH}$ range leucine has no net charge, whereas lysine has a net positive charge (Fig. 2). During experiments 3 and 4 (Tab. I) the $\mathrm{pH}$ of the permeate exceeded 10 only during the final $10 \mathrm{~min}$ and $30 \mathrm{~min}$, respectively. Since the net charge of lysine remained +1 in the concentrate and remained positive in the permeate during the major part of these runs (Fig. 2) neither a reduction in the lysine transport to the permeate compartment nor an inverse lysine transport is expected. For the isolation of cationic peptides from the LF hydrolysate, the $\mathrm{pH}$ of the feed/concentrate was kept at 8.5 while the $\mathrm{pH}$ of the permeate was kept between 4 and 7 .
We operated with transmembrane pressures (TMP) and potential difference set-points for the power supply between 0.05-2 bar and 20-40 V (average electric field strengths between the electrodes between 570-1140 V/m), respectively. At the start of some experiments the permeate section was filled with a $0.01 \mathrm{~mol} \cdot \mathrm{L}^{-1}$ $\mathrm{Na}_{2} \mathrm{SO}_{4}$ solution (also used for the electrode compartments), whereas for other experiments RO de-min. water was used to check the effect of the conductivity of the permeate on the selectivity of the separation. This resulted in a conductivity ratio, defined as the conductivity of the liquid in the permeate compartment over the conductivity of the liquid in the feed/concentrate compart-

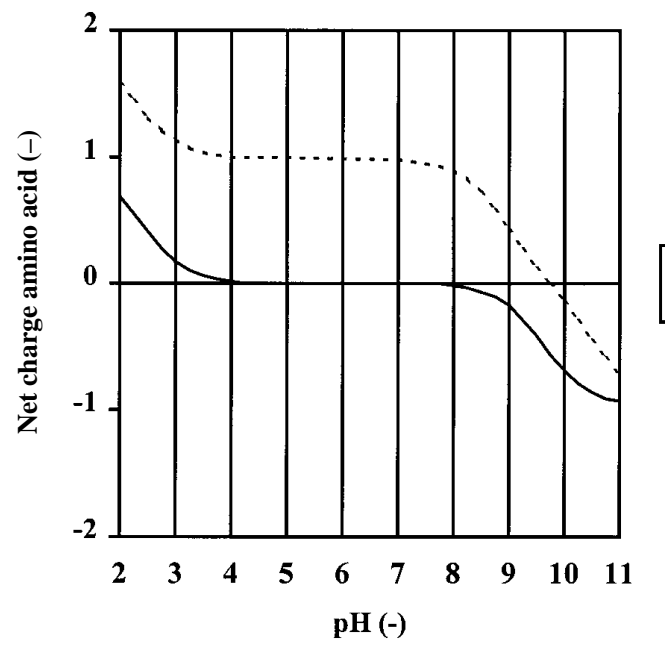

Figure 2. The net charge of leucine and lysine as function of the $\mathrm{pH}$, determined on the basis of $\mathrm{pK}$ values. 
ment of 5 for operation with $0.01 \mathrm{~mol} \cdot \mathrm{L}^{-1}$ $\mathrm{Na}_{2} \mathrm{SO}_{4}$ and below 0.01 for operation with $\mathrm{RO} \mathrm{de}-\mathrm{min}$. water using the lysine and leucine model solutions. Other operating conditions are listed in Table I.

\subsection{Analytical methods}

The amino acid analyses were done with an amino acid analyser (type 4151, LKB Biochrom, Cambridge, UK). Peptides of the LF hydrolysate were analysed by reversedphase HPLC [11]. Mass determination of peptides was performed on a Waters HPLC system connected on-line to a Quatro II triple quadrupole instrument (LC-MS) (Micromass, Cheshire, UK) as described elsewhere [12]. However, in this case a Widepore $\mathrm{C}_{18} 250 \times 20 \mathrm{~mm}$ column (Bio-Rad Laboratories, Richmond, CA, USA) was used. Peptides were eluted with linear gradient of solvent B in A going from $10 \%$ to $30 \%$ in $25 \mathrm{~min}$ at a flow-rate of $1.0 \mathrm{~mL} \cdot \mathrm{min}^{-1}$. Solvent A was a mixture of acetonitrile-watertrifluoroacetic acid (100:900:1, v/v/v) and solvent B contained the same components (900:100:0.8, v/v/v). Identification of most of the peptides in the permeate fraction was performed by reversed-phase HPLC and LC-MS using reference peptides prepared at NIZO [11]. The peptide with mass 2096 was identified by electrospray ionisationtandem mass spectrometry (ESI-MS/MS) using a Quatro II triple quadrupole mass spectrometer (Micromass) under the same conditions as reported previously [12]. The sequence of other newly identified peptides was obtained by combining the N-terminal sequence [11] and molecular mass data and matching these to the known sequence of bovine LF [8].

\section{RESULTS AND DISCUSSION}

\subsection{Separation of leucine and lysine from the model solution}

A reduction of the TMP from 2.0 to 0.5 bar hardly affected the transport of lysine through the membrane, as the reduction rate of the lysine concentration in the concentrate was practically independent of the TMP during these batch experiments (Fig. 3a). In contrast, the transport of the neutral leucine molecule decreased when a lower TMP was applied probably due to a lower water flux. Operation at a low TMP thus resulted in a higher lysine fraction in the permeate (Fig. 3b). At a TMP of 0.5 bar a lysine fraction, $f$, as high as 0.96 was obtained (Fig. 3b) starting from a lysine fraction in the feed of 0.5 (Fig. 3a). This implies that the selectivity of the process is very high. Increasing the TMP to 2.0 bar resulted in a reduction of the lysine fraction of about 0.1 to approximately 0.86 . In both situations the lysine concentration in the permeate was higher than in the feed solution. Lysine could thus be isolated and concentrated simultaneously.

Reduction of the potential difference setpoint from $40 \mathrm{~V}$ to $20 \mathrm{~V}$ reduced the lysine transport more than twofold (Fig. 4a). The relatively high lysine transport rate reduction was in line with a relatively high change in the measured potential difference over the membrane. On the basis of this observation and the independence of the lysine transport on the TMP, we conclude that the driving force for transport of the positively charged lysine was mainly governed by the electrical field strength as intended. Daufin et al. [2] described the transport of charged particles in terms of the ratio of the electromigration over the flux (UE/J, where $\mathrm{U}, \mathrm{E}$ and $\mathrm{J}$ are the electrophoretic mobility, the electrical field strength and the flux). On the basis of water fluxes reported for NTR 7450 using $0.01 \mathrm{~mol} \cdot \mathrm{L}^{-1}$ and $0.1 \mathrm{~mol} \cdot \mathrm{L}^{-1}$ leucine or lysine solutions [18] a UE/J ratio in excess of 45 is estimated for lysine transport at a potential difference set-point of $40 \mathrm{~V}$ and 2 bar operating pressure. This supports our observation, that the lysine transport is mainly governed by electromigration and thus the electrical field strength in the feed/concentrate compartment. However, the use of this ratio implicitly assumes that diffusion and the electro-osmotic flow 


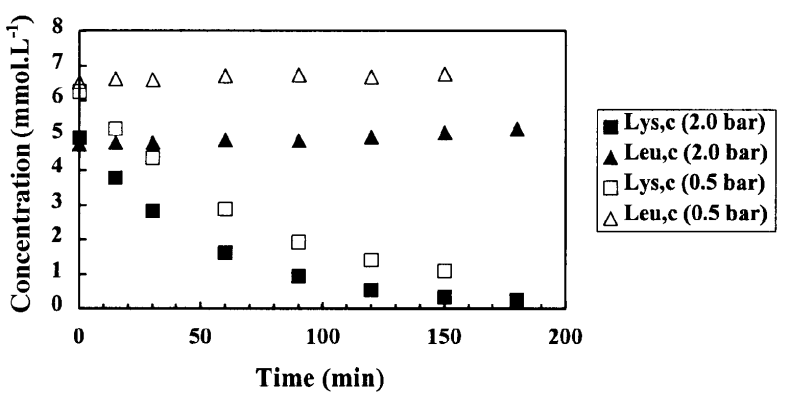

(a)

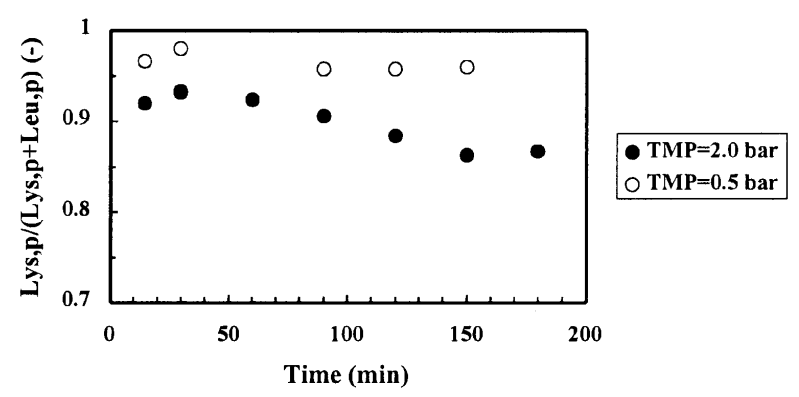

(b)

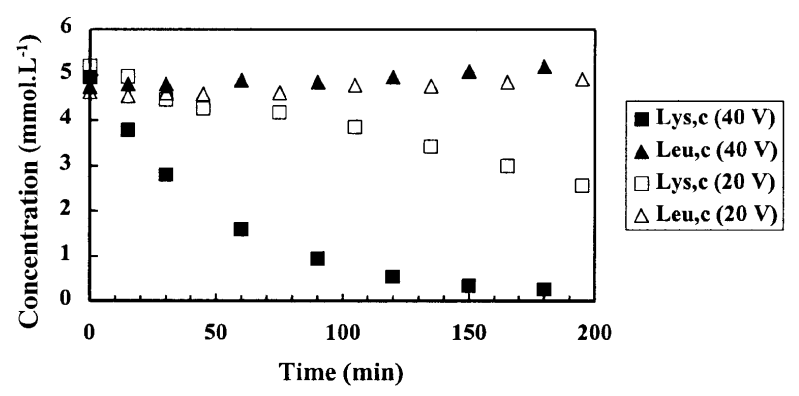

(a)

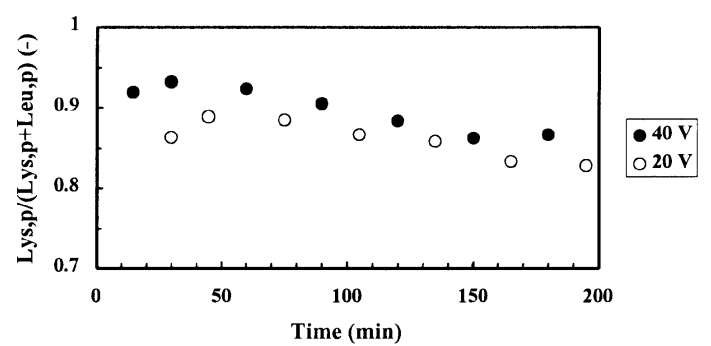

(b)

Figure 4. The effect of the potential difference on the leucine and lysine transport from the concentrate to the permeate (a) and the lysine fraction in the permeate $f$ (b) at $T M P=2.0 \mathrm{bar}$ (Leu,c and Lys,c: leucine and lysine concentration in concentrate, Leu,p and Lys,p: leucine and lysine concentration in permeate).

Figure 3. The effect of the lysine transport (a) and the lysine frac(Leu,c and Lys,c: leucine and lysine concentration in concentrate, Leu,p and Lys,p: leucine and lysine concentration in permeate). 
Figure 5. The effect of the initial permeate conductivity on the leucine and lysine concentrations in the concentrate (a) and the fraction $f$ in the permeate $(\mathbf{b})$ at $T M P=0.5$ bar and $40 \mathrm{~V}$ (description exp. 2 and 3 as listed in Tab. I).

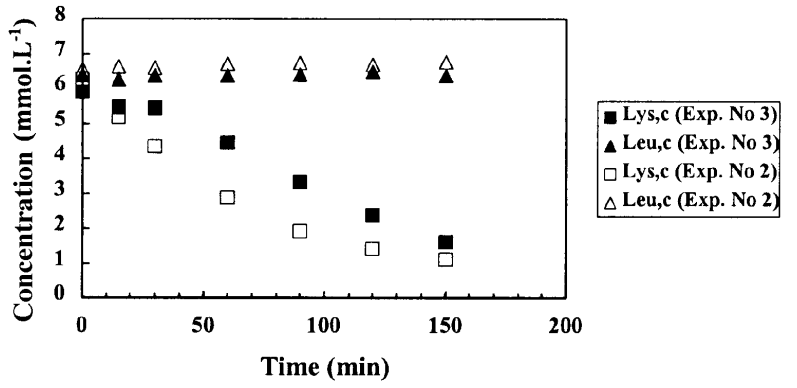

(a)

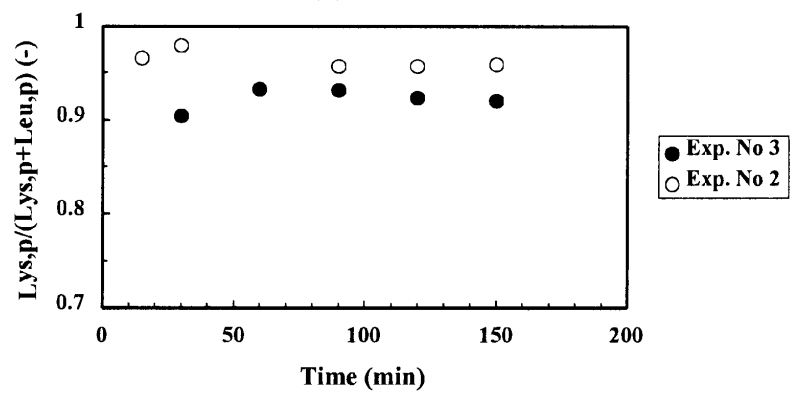

(b) can be neglected. Since the observed flux through the membrane at $T M P=2$ bar for operation without an external electrical field was below $7 \mathrm{~L} \cdot \mathrm{m}^{-2} \cdot \mathrm{h}^{-1}[18]$ it is questionable whether diffusion can be neglected entirely in relation to convection. The relative importance of the electric field over the applied pressure difference for lysine transport may therefore be overestimated by the high ratio UE/J. The leucine transport rate was also slightly lower for operation at low electrical field strength, possibly due to a lower electro-osmotic flow. The reduction in potential difference set point from 40 to $20 \mathrm{~V}$ consequently resulted in a lysine fraction decrease of 0.04 (Fig. 4b). This difference in the lysine fraction in the permeate $f$ reduced with progressing of the runs. Due to a higher initial transport rate for lysine at a high electrical field strength, the lysine concentration in the concentrate was reduced faster during batch wise operation. As a result the lysine transport rate for operation at higher electrical field strength was reduced more with progressing of the run. In combination with a relatively stable leucine concentration in the concentrate and leucine transport to the permeate, the lysine fraction in the permeate was reduced with progressing of the run, especially for operation at high potential difference set point. Although the $\mathrm{pH}$ of the permeate was not adjusted at the low potential difference, this most likely did not affect the observed change in lysine transport rate and lysine fraction in the permeate, as explained earlier.

Operation with $0.01 \mathrm{~mol} \cdot \mathrm{L}^{-1} \mathrm{Na}_{2} \mathrm{SO}_{4}$ in the permeate compartment at start of the run resulted in a significantly higher lysine transport rate (Fig. 5a) than operation with RO de-min. water. The use of a permeate with higher conductivity enhanced the lysine transport rate as a result of an increase in electric field strength in the feed/concentrate compartment at an unchanged potential difference set-point over the electrodes and thus a higher driving force for transport of 


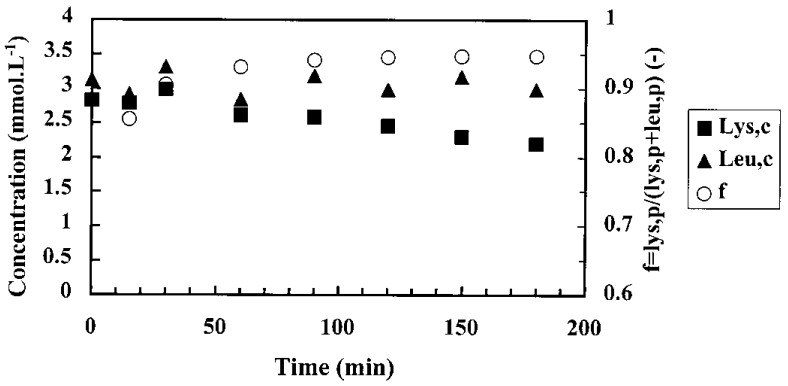

Figure 6. Leucine and lysine concentrations in the concentrate and the lysine fraction in the permeate, $f$, for EMF of casein hydrolysate at $T M P=$ 0.05 bar and $40 \mathrm{~V}$. charged components (e.g. [20]). The leucine transport rate was hardly affected by the permeate conductivity at start of the run, as expected. Consequently the lysine fraction, $\mathrm{f}$, was significantly higher, when filtration was started with a liquid with high conductivity $\left(0.01 \mathrm{~mol} \cdot \mathrm{L}^{-1} \mathrm{Na}_{2} \mathrm{SO}_{4}\right.$ solution $)$ in the permeate chamber (Fig. 5b). However, since the leucine concentration relative to the lysine concentration in the permeate was very low for both cases, the difference in lysine fraction was less than $f=0.05$ (Fig. 5b).

\subsection{Separation of leucine and lysine from a casein hydrolysate}

Lysine and leucine could also be separated from a casein hydrolysate at a lysine fraction in the permeate as high as $f=0.95$ (Fig. 6). This fraction is similar to the maximum fraction obtained with our leucine/ lysine model solution, starting with similar lysine fractions in the feed of 0.5 . The permeate concentrations of all the other amino acids, apart from arginine were similar to that for leucine. This observation is in line with conclusions from Daufin et al. [2], who studied the separation of amino acids from a model solution. Lysine can thus be removed from the casein hydrolysate with a high selectivity. However, the lysine transport rate through the membrane was substantially lower than found for our model solution. The transport rate can be improved by optimisation of the process conditions (e.g. loading the permeate compartment with a solution with higher conductivity before the start of the run).

\subsection{Isolation of cationic peptides from a lactoferrin hydrolysate}

Cationic peptides could be separated successfully from a LF hydrolysate. The HPLC analysis of the total permeate collected after $180 \mathrm{~min}$ of operation revealed a seven-peak profile (Fig. 7). Five peptides (Tab. II) had been previously found in an antibacterial fraction obtained from a LF hydrolysate by cation-exchange chromatography [11], including the potent bactericidal peptide Lfcin-B (fragments 17-41 or 17-42 of LF) [1]. Interestingly, the combination of the $\mathrm{N}$-terminal sequence and MS data revealed that the peptides eluting at $41.2 \mathrm{~min}$ also correspond to the fragments identified as Lfcin-B, but in the oxidised form (Met $\rightarrow$ MetO). All the identified peptides in the EMF permeate had a net positive charge. At least three of the identified peptides, the heterodimer with mass 2430 (Tab. II) and fragments $17-41$ and 17-42 (Lfcin-B), have been shown to be antibacterial $[1,3,11]$. The Lfcin-B transport rate was relatively low (Fig. 8). Nevertheless, we have shown that with EMF, cationic peptides can be separated selectively from a LF hydrolysate with a product composition similar to that obtained by cation-exchange chromatography [11]. Operating conditions can be further optimised to improve the separation efficiency and transport rate. 


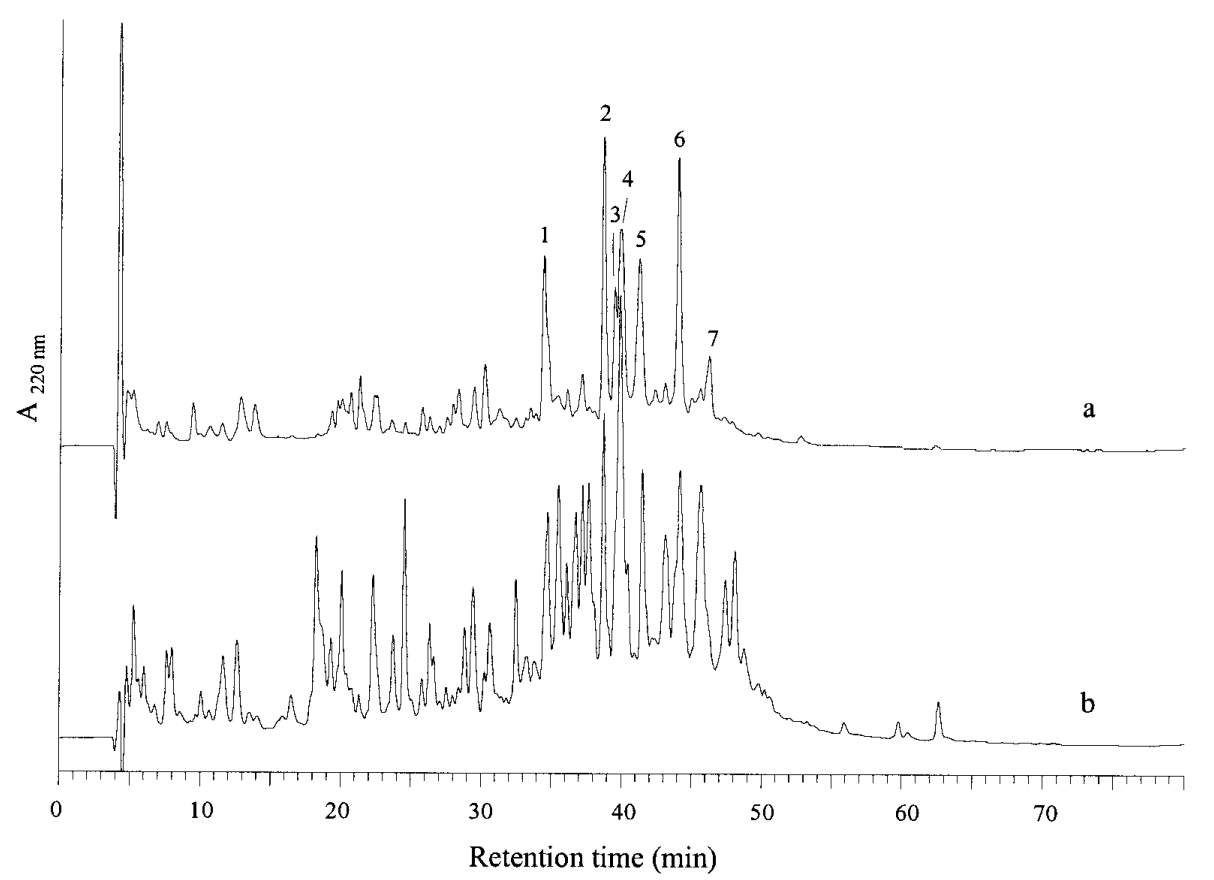

Figure 7. Reversed-phase HPLC chromatograms of the permeate obtained after $180 \mathrm{~min}$ EMF (a) and the LF feed solution (b) (Tab. II).

Table II. Mass determination and peptide identification of the peptic LF fragments obtained in the permeate compartment after EMF during $180 \mathrm{~min}$.

\begin{tabular}{|c|c|c|c|c|c|c|}
\hline $\begin{array}{l}\text { Peak } \\
\text { No. }^{\text {e }}\end{array}$ & $\begin{array}{l}\text { Retention } \\
\text { time }\end{array}$ & $\begin{array}{l}\text { Observed } \\
\text { mass }\end{array}$ & $\begin{array}{l}\text { Theoretical } \\
\text { mass }^{\mathrm{a}}\end{array}$ & $\begin{array}{l}\text { Net } \\
\text { charge }\end{array}$ & $\begin{array}{l}\text { Sequence } \\
\text { position }^{\text {b }}\end{array}$ & $\begin{array}{l}\text { Identified } \\
\text { by }\end{array}$ \\
\hline 1 & 34.3 & 2096 & 2096.4 & +4 & $271-288$ & This work $^{\mathrm{c}}$ \\
\hline 2 & 38.6 & $\begin{array}{l}1568 \\
4276\end{array}$ & $\begin{array}{c}1568.8 \\
\text { not identified }\end{array}$ & +2 & $618-631$ & This work $^{\mathrm{d}}$ \\
\hline 3 & 39.4 & 2430 & 2430.8 & +3 & $(1-16)-S-S-(45-48)$ & [11] \\
\hline 4 & 39.9 & 2248 & 2248.7 & +5 & $267-285$ & [11] \\
\hline 5 & 41.2 & $\begin{array}{l}3140 \\
3211\end{array}$ & $\begin{array}{l}3139.8 \\
3210.9\end{array}$ & $\begin{array}{l}+8 \\
+8\end{array}$ & $\begin{array}{l}\text { 17-41 (oxidised Met) } \\
17-42 \text { (oxidised Met) }\end{array}$ & This work ${ }^{\mathrm{d}}$ \\
\hline 6 & 44.0 & $\begin{array}{l}3123 \\
3194\end{array}$ & $\begin{array}{l}3123.8 \\
3194.9\end{array}$ & $\begin{array}{l}+8 \\
+8\end{array}$ & $\begin{array}{l}17-41 \\
17-42\end{array}$ & {$[1,3,11]$} \\
\hline 7 & 46.2 & 2636 & 2637.1 & +5 & $267-288$ & [11] \\
\hline
\end{tabular}

${ }^{a}$ Average mass values.

${ }^{\mathrm{b}}$ LF sequence [8].

${ }^{\mathrm{c}}$ Identified by electrospray ionization-tandem mass spectrometry.

${ }^{\mathrm{d}}$ Identified by combining the $\mathrm{N}$-terminal sequence and the molecular mass data.

${ }^{\mathrm{e}}$ See Figure 7. 


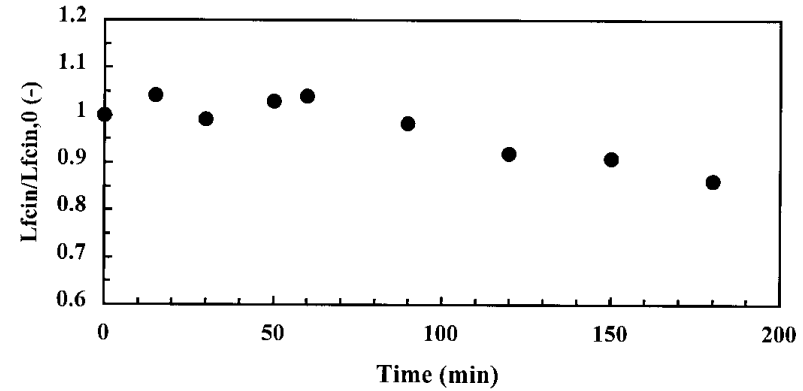

Figure 8. Reduction of the Lfcin-B concentration in the concentrate relative to the initial Lfcin-B concentration for EMF of LF hydrolysate at $T M P=$ 0.05 bar and $40 \mathrm{~V}$.

\section{CONCLUSION}

Electro-membrane filtration can be used to separate the amino acids leucine and lysine not only from model solutions, but also from a protein hydrolysate at a lysine fraction in the permeate of approximately 0.96 . This implies that the selectivity for the separation of leucine and lysine with EMF is very high. A transmembrane pressure increase from 0.5 to 2.0 bar results in a reduction of the lysine fraction of about 0.10 to 0.86 at practically unchanged lysine transport rate. An increase in the applied potential difference from 20 to $40 \mathrm{~V}$ results in a more than twofold increase in lysine transport rate and a lysine fraction increase of 0.04 in the permeate. Increasing the conductivity of the solution in the permeate compartment at the start of the run results in a higher lysine transport rate and a higher lysine fraction in the permeate.

With EMF a fraction enriched in antibacterial cationic peptides can be produced from a LF hydrolysate. The composition of the fraction produced is similar to that obtained with classical cation-exchange chromatography.

\section{ACKNOWLEDGEMENTS}

We would like to thank R. Holleman, T. Robbertsen, C. Slangen for the analytical work and for the discussions on the subject. We also gratefully acknowledge P. Aimar for providing the membrane module. I. Recio acknowledges the European Commission for a scholarship.

\section{REFERENCES}

[1] Bellamy W., Takase M., Yamauchi K., Wakabayashi H., Kawase K., Tomita M., Identification of the bactericidal domain of lactoferrin, Biochim. Biophys. Acta 1121 (1992) 130-136.

[2] Daufin G., Kerhervé F.L., Aimar P., Mollé D., Léonil J., Nau F., Electrofiltration of solutions of amino acids or peptides, Lait 75 (1995) 105-115.

[3] Dionysius D.A., Milne J.M., Antibacterial peptides of bovine lactoferrin: purification and characterization, J. Dairy Sci. 80 (1997) 667-674.

[4] Garem A., Daufin G., Maubois J.-L., Léonil J., Selective separation of amino acids with charged inorganic nanofiltration membrane: Effect of physicochemical parameters on selectivity, Biotechnol. Bioeng. 54 (1997) 291-302.

[5] Ikeda K., Nakano T., Ito H., Kubota T., Yamamoto S., New composite charged reverse osmosis membrane, Desalination 68 (1988) 109-119.

[6] Lentsch S., Aimar P., Orozco J.L., Enhanced separation of albumin-poly (ethylene glycol) by combination of ultrafiltration and electrophoresis, J. Membrane Sci. 80 (1993) 221-232.

[7] Nau F., Kerhervé F.L., Léonil J., Daufin G., Selective separation of tryptic beta-casein peptides through ultrafiltration membranes: influence of ionic interactions, Biotechnol. Bioeng. 46 (1995) 246-253.

[8] Pierce A., Colavizza D., Benaissa M., Maes P., Tartar A., Montreuil J., Spik G., Molecular cloning and sequence analysis of bovine lactotransferrin, Eur. J. Biochem. 196 (1991) 177-184.

[9] Pouliot Y., Gauthier S.F., Bard C., Fractionation of casein hydrolysates using polysulphone ultrafiltration hollow fiber membranes, J. Membrane Sci. 80 (1993) 257-264.

[10] Radovich J.M., Behnam B., Concentration ultrafiltration and diafiltration of albumin with an electric field, Separ. Sci. Technol. 18 (1983) 215-222. 
[11] Recio I., Visser S., Two ion-exchange chromatographic methods for the isolation of antibacterial peptides from lactoferrin. In situ enzymatic hydrolysis on an ion-exchange membrane, J. Chromatogr. A 831 (1999) 191-201.

[12] Recio I., Visser S., Identification of two distinct antibacterial domains within the sequence of bovine $\alpha$-casein, Biochim. Biophys. Acta 1420 (1999) 314-326.

[13] Rios G.M., Freud P., Design and performance of ceramic EUF process for protein concentration, Key Eng. Mat. 61/62 (1991) 255-260.

[14] Rios G.M., Rakotoarisoa H. Tarado de la Fuente B., Basic transport mechanisms of ultrafiltration in the presence of an electric field, J. Membrane Sci. 38 (1988) 147-159.

[15] Robinson C.W., Siegel M.H., Condemine A., Fee C., Fahidy T.Z., Glick B.R., Pulsed-electric-field crossflow ultrafiltration of bovine serum albumin, J. Membrane Sci. 80 (1993) 209-220.

[16] Saksena S., Zydney A.L., Effect of solution pH and ionic strength on the separation of albumin from immunoglobulins (IgG) by selective filtration, Biotechnol. Bioeng. 43 (1994) 960-968.
[17] Timmer J.M.K., van der Horst H.C., Whey processing and separation technology: State-of-theart and New developments, Proceedings of the second international Whey Conference held in Chicago, USA, 27-29 October 1997, International Dairy Federation, Brussels.

[18] Timmer J.M.K., Speelmans M.P.J., van der Horst H.C., Separation of amino acids by nanofiltration and ultrafiltration membranes, Separ. Purif. Technol. 14 (1998) 133-144.

[19] Tsuru T., Shutou T., Nakao S.I., Kimura S., Peptide and amino acid separation with nanofiltration membranes, Separ. Sci. Technol. 29 (1994) 971-984.

[20] van Nunen C.A.P.M., Design of a large scale membrane-electrophoresis module for separation of proteins, Dissertation Thesis, Eindhoven University of Technology, Eindhoven, The Netherlands, 1997.

[21] Walsh C.J., Thomas R.L., Kunkel M.E., The use of metallic ultrafiltration membranes to access calcium availability in vitro, Food Chem. 32 (1989) 307-317.

[22] Yukawa H., Shimura K., Suda A., Maniwa A., Cross flow electro-ultrafiltration for colloidal solution of protein, J. Chem. Eng. Jpn. 16 (1983) 305-311. 